\title{
Implementasi Model Discovery Learning Berbantuan Powerpoint Terhadap Hasil Belajar IPA
}

\author{
Kt. Novi Ariawati1 ${ }^{*}$, I Md. Suarjana ${ }^{2}$, Gd. Agus Sudarmawan ${ }^{3}$ (iD \\ 1,2 Pendidikan Profesi Guru Prajabatan, Universitas Pendidikan Ganesha, Singaraja, Indonesia \\ ${ }^{3}$ Sekolah Dasar Negeri 4 Kampung Baru, Singaraja, Indonesia \\ *Corresponding author: ariawatinovi@gmail.com
}

\begin{abstract}
Abstrak
Pembelajaran yang berlangsung kurang menggunakan model pembelajaran yang inovatif dan media pembelajaran yang belum digunakan secara optimal. Sehingga menyebabkan hasil belajar IPA masih rendah. Penelitian ini bertujuan mengetahui implementasi model discovery learning berbantuan powerpoint untuk meningkatkan hasil belajar IPA kelas IV. Penelitian ini menggunakan jenis penelitian tindakan kelas dengan dua siklus. Subjek penelitian ini adalah siswa kelas IV yang berjumlah 41 siswa yang terdiri atas 21 siswa laki-laki dan 20 siswa perempuan. Data hasil belajar IPA dikumpulkan dengan metode tes bentuk pilihan ganda. Data hasil penelitian dianalisis dengan teknik analisis statistik deskriptif kuantitatif. Hasil penelitian menunjukkan bahwa rata-rata hasil belajar pra siklus adalah 62,80 dengan ketuntasan belajar 46,34\%. Hasil belajar siklus I meningkat dengan rata-rata sebesar 68,05 dan ketuntasan belajar 60,98\%. Rata-rata hasil belajar siklus II meningkat menjadi 75,85 dengan ketuntasan belajar 82,93\%. Jadi, implementasi model discovery learning berbantuan powerpoint dapat meningkatkan hasil belajar IPA siswa. Implikasi yaitu pembelajaran lebih menekankan pada aktivitas siswa, adanya media pembelajaran siswa lebih tertarik, melalui penemuan materi diingat lebih lama, pembelajaran yang dilaksanakan meningkatkan kemampuan berpikir kritis serta hasil belajar siswa.
\end{abstract}

Kata kunci: discovery learning, hasil belajar, powerpoint

\section{Abstract}

Learning that took place did not use innovative learning models and the learning media had not been used optimally. So that caused natural science learning outcomes to be low. This research aims to determine the implementation of the powerpoint assisted discovery learning model to improved natural science learning outcomes for class IV. This research use classroom action research with two cycles. The subjects of this research were fourth grade students, totaling 41 students consisting of 21 male students and 20 female students. Natural science learning outcomes data was collected using the multiple-choice test method. The researched data was analyzed using quantitative descriptive statistical analysis techniques. The results showed that the average pre-cycle learning outcome was 62,80 with learning completeness 46,34\%. The learning outcomes of the first cycle increased by an average of 68,05 and learning completeness was 60,98\%. The average learning outcomes in the second cycle increased to 75,85 with learning completeness of 82,93\%. So, implementing the powerpoint assisted discovery learning model could improved student's natural science learning outcomes. The implication is that learning emphasizes more on student activities, the existence of learning media students is more interested, through the discovery of material that is remembered longer, the learning carried out improves critical thinking skills and student learning outcomes.

Keywords: discovery learning, learning outcomes, powerpoint

$\begin{array}{ll}\text { History: } & \text { Publisher: Undiksha Press } \\ \text { Received : 11 April 2021 } & \text { Licensed: This work is licensed under } \\ \text { Revised : 15 April 2021 } & \text { a Creative Commons Attribution 4.0 License } \\ \text { Accepted : 17 Juni 2021 } & \text { Published : 25 Juli 2021 }\end{array}$

\section{Pendahuluan}

IPA adalah salah satu mata pelajaran yang terdapat pada sekolah dasar (SD). Mata pelajaran IPA dalam kurikulum 2013 terintegrasi dalam mata pelajaran tematik. IPA berkaitan dengan kejadian yang terjadi di alam semesta beserta isinya. Setiap kejadian yang terjadi akan diselidiki dan dianalisa secara sistematis dan terstruktur untuk mendapatkan pembuktian yang memiliki nilai pasti. IPA digunakan untuk menggali informasi tentang kejadian-kejadian alam melalui proses ilmiah. Pembelajaran IPA sangat penting untuk 
dipelajari karena dapat melatih siswa berpikir kritis dan objektif serta bermanfaat untuk memupuk rasa ingin tahu siswa secara alamiah. Selain itu, pembelajaran IPA SD menanamkan sikap-sikap luhur seperti peduli terhadap lingkungan sekitar dan bertanggung jawab pada kelangsungan alam tersebut (Asriani, Pahriadi, 2021; Tembang et al., 2019). Pembelajaran IPA bukan hanya memberikan materi begitu saja dan tidak bersifat hafalan. Namun, pembelajaran IPA di SD harus dibelajarakan dengan kegiatan-kegiatan yang mengarahkan siswa untuk aktif dalam pembelajaran seperti ekseperimen atau percobaan. Melalui kegiatan tersebut pembelajaran IPA dapat menumbuhkan sikap-sikap ilmiah dan keterampilan proses, terjadi proses yang dialami siswa untuk menemukan produk-produk sains atau IPA (Azizah et al., 2021; Elisa et al., 2013). Jadi, pembelajaran IPA di SD sudah seharusnya dilaksanakan melalui pemberian pengalaman langsung, pembelajaran yang menyenangkan dan meningkatkan partisipasi siswa. Sehingga, siswa dapat memahami materi secara lebih mendalam dan dapat diingat dalam waktu yang relatif lama.

Namun kenyataannya pembelajaran yang berlangsung di SD masih belum sesuai harapan. Berdasarkan pengamatan dan wawancara yang dilakukan dalam pembelajaran IPA, masih ada siswa yang malu-malu untuk menjawab pertanyaan yang diajukan guru maupun bertanya. Hal ini dikarenakan siswa merasa takut salah dalam memberikan tanggapan atau pendapat. Pembelajaran yang berlangsung kurang menggunakan model pembelajaran inovatif dan kurang optimal dalam menggunakan media pembelajaran yang dapat memicu semangat siswa untuk belajar. Sehingga, semangat dan motivasi siswa saat mengikuti pembelajaran rendah. Hal tersebut berakibat pada hasil belajar muatan IPA rendah. Hal tersebut didukung oleh hasil studi dokumentasi pada penilaian akhir semester I yang menunjukkan hasil belajar IPA siswa kelas IV belum maksimal, nilai siswa masih ada yang di bawah KKM. Nilai ratarata hasil belajar IPA sebesar 62,80. Dari 41 siswa hanya 19 siswa yang sudah mencapai nilai baik dan tuntas dengan persentase $46,34 \%$ dan terdapat 22 siswa dengan persentase $53,66 \%$ yang mendapatkan nilai rendah. Hasil tersebut menunjukkan bahwa lebih banyak siswa yang mendapatkan nilai rendah dan belum tuntas. Itu menandakan hasil belajar muatan IPA belum optimal dan masih rendah. Fakta tersebut juga diungkap oleh beberapa penelitian sebelumnya yang menyatakan pembelajaran IPA masih didominasi oleh guru dengan menggunakan metode ceramah (Kusumah et al., 2020; Nurqomariah, Gunawan, 2015; Zairmi et al., 2019). Pembelajaran IPA yang demikian menyebabkan peran siswa dalam pembelajaran menjadi sangat minim karena siswa hanya dapat mendengarakan penjelasan dari guru tanpa diberikan kebebasan untuk mengeksplorasi pengetahuan dengan sendiri. Permasalah tersebut jika terus dibiarkan, maka berdampak pada tidak tercapainya tujuan pembelajaran dan lulusan yang kurang berkualitas.

Salah satu upaya untuk mengatasi permasalahan tersebut, guru harus mampu merancang model pembelajaran yang inovatif bagi siswa. Model pembelajaran yang dapat menarik minat siswa, meningkatkan keaktifan siswa, dan melibatkan siswa secara penuh dalam pembelajaran. Salah satu model pembelajaran yang dapat digunakan yaitu model discovery learning. Model discovery learning atau yang sering disebut dengan model penemuan merupakan model pembelajaran yang direkomendasikan pada kurikulum 2013, yang mana penggunaan model discovery learning dapat merubah paradigma pendidikan menjadi berpusat pada siswa (student center). Pembelajaran memberikan kesempatan seluaslusanya untuk siswa dapat terlibat dalam pembelajaran yang mengarahkan mereka menemukan konsep. (Cintia, 2018; Razi, 2019; Whesli et al., 2021). Model pembelajaran discovery learning mampu mengembangkan proses berpikir tingkat tinggi siswa baik berpikir kritis maupun berpikir kreatif. Hal ini dimaksud karena materi yang dipelajari tidak lagi diberikan langsung dan siswa tidak lagi hanya berdiam diri menerima materi begitu saja melainkan mereka akan melalui proses untuk menemukan sebuah pengetahuan atau informasi (Winoto \& Prasetyo, 2020). Penggunaan model discovery learning dapat menciptakan 
pembelajaran yang bermakna bagi siswa karena dalam pembelajaran melalui penemuan yang dilakukan, siswa dapat menghubungkan pengetahuan atau informasi yang didapatkan selama penemuan dengan pengetahuan atau informasi yang sudah dimiliki sebelumnya (Rosarina et al., 2016). Belajar dengan penemuan memberikan pengalaman langsung yang dialami siswa dalam memecahkan persoalan dengan berbagai kegiatan yang dilalui. Dengan demikian, pembelajaran discovery learning dapat meningkatkan pemahaman dan menguatkan ingatan siswa terhadap materi yang dipelajari. (Nilayuniarti \& Putra, 2020; Winoto \& Prasetyo, 2020). Pada pembelajaran menggunakan model discovery learning, guru berperan sebagai fasilitator dan motivator, yakni sebagai penyedia sumber belajar dan mendorong atau memberikan semangat kepada siswa untuk berusaha menemukan konsep materi dan bekerja keras untuk dapat mengikuti pembelajaran dengan baik.

Pembelajaran dengan menerapkan model discovery learning dibantu dengan media powerpoint. Penggunaan media dapat membangkitkan keinginan dan minat, membangkitkan motivasi dan merangsang kegiatan belajar. Media powerpoint merupakan salah satu media pembelajaran yang membantu guru dalam pembelajaran. Powerpoint merupakan program aplikasi persentasi yang terdapat pada microsoft office yang dapat menarik perhatian siswa karena penggunaan warna, menampilkan video, gambar, dan memiliki desain template yang beragam dan unik. (Nurhidayati et al., 2019; Sutama, 2020). Selain itu, media powerpoint juga sangat praktis untuk dibawa kemana-mana karena powerpoint yang sudah dibuat dapat disimpan dengan mudah di $\mathrm{CD}$, flashdisk maupun harddisk. Oleh karena itu, media powerpoint yang sudah dibuat dapat digunakan kembali untuk pembelajaran di kelas yang sama pada tahun yang berbeda (Purwanti et al., 2020; Siboro, 2020).

Pembelajaran dengan model discovery learning sudah banyak dilakukan pada penelitian sebelumnya baik pada jenjang SD, SMP, SMA, maupun perguruan tinggi. Penelitian ini berbeda dengan penelitian sebelumnya karena pembelajaran dengan model discovery learning dilaksanakan secara daring dengan aplikasi google meet, google classroom, dan whatsapp serta dalam pembelajaran dilengkapi dengan penggunaan media powerpoint. Sehubungan dengan masalah-masalah yang ditemukan dan solusi, maka tujuan dari penelitian ini yaitu untuk mengetahui implementasi model discovery learning berbantuan powerpoint terhadap hasil belajar IPA siswa kelas IV di SD Negeri 21 Pemecutan tahun ajaran 2020/2021.

\section{Metode}

Penelitian ini merupakan jenis penelitian tindakan kelas (PTK). Penelitian tindakan kelas (PTK) merupakan sebuah kegiatan yang dilakukan oleh guru secara sistematis dan menggunakan metodelogi untuk memberikan tindakan atas permasalahan yang terjadi di kelas untuk memperbaiki kualitas pembelajaran yang lebih baik (H. Muhammad, 2015; Mulyasa, 2013). Dalam penelitian tindakan kelas, guru sebagai peneliti yang melaksanakan dan mengamati pelaksanaan pembelajaran, guru lain juga dapat ikut dalam penelitian ini sebagai pengamat yang membantu guru peneliti dalam memberikan masukkan sebagai bahan refleksi terhadap pelaksanaan penelitiannya. Penelitian tindakan kelas dilaksanakan dengan dua siklus. Setiap siklus terdiri atas pemberian tindakan kelas dan pemberian tes akhir siklus (posttest). Setiap siklus terdiri atas empat tahapan yaitu perencanaan, pelaksanaan, observasi, dan refleksi. Pada tahap perencanaan beberapa kegiatan yang dilakukan yaitu membuat RPP menggunakan model pembelajaran discovery learning berbantuan media powerpoint, membuat dan menyiapkan bahan ajar dan LKPD, menyiapkan media pembelajaran, dan menyusun evaluasi. Pada tahap pelaksanaan, melaksanakan pembelajaran sesuai dengan RPP yang telah disusun. Pada tahap observasi dilakukan pengamatan terhadap pelaksanaan pembelajaran dengan membuat catatan tentang kejadian yang terjadi selama pembelajaran. 
Tahap observasi dilaksanakan pada tahap pelaksanaan. Tahap refleksi dilakukan kegiatan mengidentifikasi hambatan atau kendala-kendala yang dihadapi pada tiap siklus dan mencari penyebab dari kendala tersebut. Kemudian mencari dan merumuskan alternatif sebagai upaya perbaikan. Secara umum rancangan penelitian tindakan kelas tampak pada Gambar 1.

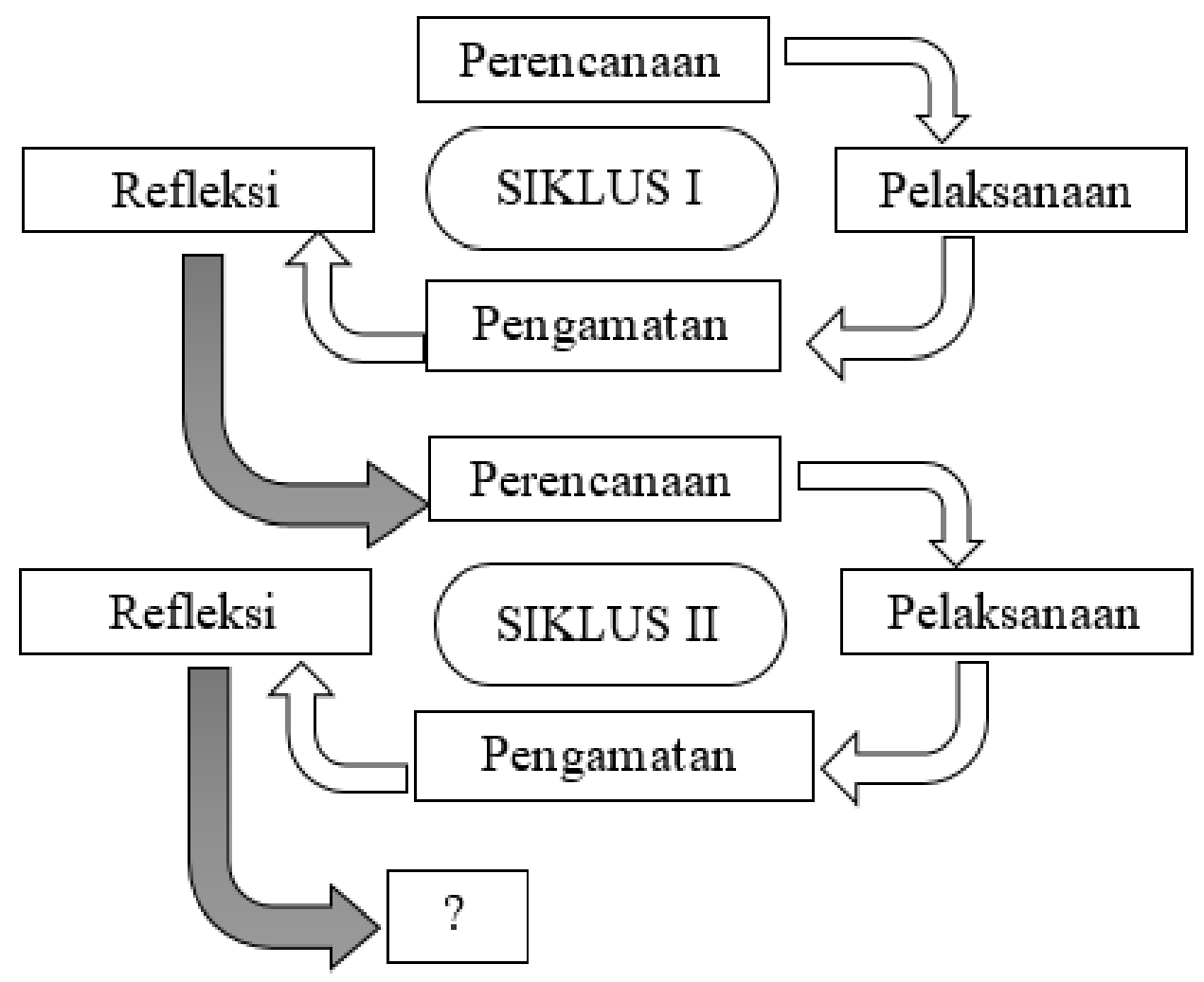

Gambar 1. Siklus Penelitian Tindakan Kelas (Jarre \& Bachtiar, 2017)

Subjek penelitian ini adalah siswa kelas IV SD Negeri 21 Pemecutan tahun ajaran 2020/2021. Jumlah siswa adalah 41 siswa yang terdiri atas 21 siswa laki-laki dan 20 siswa perempuan. Objek penelitian ini adalah hasil belajar muatan IPA dengan menerapkan model discovery learning berbantuan powerpoint. Data yang dikumpulkan dalam penelitian adalah data hasil belajar muatan IPA pada ranah kognitif. Metode yang digunakan untuk mengumpulkan data hasil belajar muatan IPA adalah metode tes. Metode tes adalah pengumpulan data dengan bentuk tugas yang harus dikerjakan siswa untuk mengetahi hasil belajarnya (Sri Udayanti \& Nanci Riastini, 2017). Instrumen yang digunakan untuk mengumpulkan data adalah tes objektif tipe pilihan ganda yang berjumlah 10 butir soal. Setiap soal disertai dengan empat alternatif jawaban (a, b, c, dan d) yang dapat dipilih oleh siswa. Setiap butir soal diberikan skor 1 apabila siswa dapat menjawab dengan benar dan skor 0 apabila menjawab salah. Sebelum menyusun instrumen terlebih dahulu dilakukan penyusunan kisi-kisi. Kisi-kisi dibuat agar menghindari penyusunan instrumen penelitian yang menyimpang dari indikator yang telah ditetapkan. Adapun kisi-kisi intrumen yang digunakan dapat dilihat pada Tabel 1. 
Tabel 1. Kisi-kisi Instrumen Penelitian

\begin{tabular}{|c|c|c|c|c|}
\hline Siklus & Kompetensi Dasar & Indikator & $\begin{array}{c}\text { Level } \\
\text { Kognitif }\end{array}$ & $\begin{array}{l}\text { No. } \\
\text { Soal }\end{array}$ \\
\hline \multirow[t]{9}{*}{ I } & 3.3. & Menjelaskan pengertian gaya. & $\mathrm{C} 2$ & 1 \\
\hline & $\begin{array}{l}\text { Mengidentifikasi } \\
\text { macam-macam }\end{array}$ & $\begin{array}{l}\text { Menganalisis macam-macam gaya dan } \\
\text { pengaruhnya terhadap benda. }\end{array}$ & $\mathrm{C} 4$ & 2,3 \\
\hline & $\begin{array}{l}\text { gaya, antara lain: } \\
\text { gaya otot, gaya }\end{array}$ & $\begin{array}{l}\text { Mengkategorikan kegiatan yang } \\
\text { menggunakan gaya. }\end{array}$ & C6 & 4 \\
\hline & $\begin{array}{l}\text { listrik, gaya magnet, } \\
\text { gaya gravitasi, dan }\end{array}$ & $\begin{array}{l}\text { Menganalisis kegiatan yang } \\
\text { menunjukkan gaya otot. }\end{array}$ & $\mathrm{C} 4$ & 5 \\
\hline & gaya gesekan. & $\begin{array}{l}\text { Menganalisis manfaat gaya otot dalam } \\
\text { kehidupan sehari-hari. }\end{array}$ & $\mathrm{C} 4$ & 6 \\
\hline & & $\begin{array}{l}\text { Mengkategorikan kegiatan yang } \\
\text { menggunakan gaya otot pada manusia } \\
\text { dan hewan. }\end{array}$ & C6 & 7 \\
\hline & & $\begin{array}{l}\text { Menjelaskan manfaat gaya listrik } \\
\text { dalam kehidupan manusia. }\end{array}$ & $\mathrm{C} 2$ & 8 \\
\hline & & Menjelaskan pengertian listrik statis. & $\mathrm{C} 2$ & 9 \\
\hline & & $\begin{array}{l}\text { Mengkategorikan listrik statis dalam } \\
\text { kehidupan sehari-hari. }\end{array}$ & C6 & 10 \\
\hline \multirow[t]{8}{*}{ II } & 3.4 Menghubungkan & Menjelaskan pengertian gaya. & $\mathrm{C} 2$ & 1 \\
\hline & gaya dengan & Menjelaskan pengertian gerak. & $\mathrm{C} 2$ & 2 \\
\hline & $\begin{array}{l}\text { gerak pada } \\
\text { peristiwa di }\end{array}$ & $\begin{array}{l}\text { Menganalisis pengaruh gaya terhadap } \\
\text { benda. }\end{array}$ & $\mathrm{C} 4$ & 3,4 \\
\hline & $\begin{array}{l}\text { lingkungan } \\
\text { sekitar. }\end{array}$ & $\begin{array}{l}\text { Membandingkan pengaruh gaya } \\
\text { terhadap gerak benda. }\end{array}$ & $\mathrm{C} 5$ & 5 \\
\hline & & $\begin{array}{l}\text { Menganalisis pengaruh gaya terhadap } \\
\text { kecepatan dan arah gerak benda. }\end{array}$ & $\mathrm{C} 4$ & 6,7 \\
\hline & & $\begin{array}{l}\text { Mengkategorikan peristiwa yang } \\
\text { melibatkan gaya tarik dan gaya dorong. }\end{array}$ & C6 & 8 \\
\hline & & $\begin{array}{l}\text { Menganalisis pengaruh gaya terhadap } \\
\text { perubahan bentuk benda. }\end{array}$ & $\mathrm{C} 4$ & 9 \\
\hline & & $\begin{array}{l}\text { Menghubungkan besar kecil gaya } \\
\text { dengan perubahan bentuk benda. }\end{array}$ & C6 & 10 \\
\hline
\end{tabular}

Data penelitian yang telah dikumpulkan kemudian dilakukan analisis data. Analisis data dengan menggunakan analisis statistik deskriptif kuantitatif untuk mendeskripsikan data hasil belajar muatan IPA siswa. Data yang dianalisis antara lain menghitung mean atau ratarata, menghitung daya serap, dan menghitung ketuntasan belajar. Hasil analisis tingkat hasil belajar siswa ditentukan dengan ketuntasan belajar siswa yang dikonversikan ke dalam penilaian acuan patokan (PAP) skala lima seperti Tabel 2.

Tabel 2. Kriteria Penilaian Acuan Patokan (PAP) Skala Lima tentang Hasil Belajar Siswa

\begin{tabular}{cc}
\hline Tingkat penguasaan & Kategori \\
\hline $85 \%-100 \%$ & Sangat Tinggi \\
$70 \%-84 \%$ & Tinggi \\
$55 \%-69 \%$ & Cukup \\
$40 \%-54 \%$ & Rendah \\
$0-39 \%$ & Sangat Rendah \\
\hline
\end{tabular}


Kriteria keberhasilan adalah pedoman yang digunakan untuk menentukan berhasil atau tidaknya sebuah penelitian. Nilai minimal hasil belajar IPA yang ditargetkan adalah 69 sesuai dengan KKM. Kriteria keberhasilan penelitian ini yaitu ketuntasan belajar mencapai minimal $75 \%$ berada pada kategori tinggi. Jika kriteria keberhasilan sudah dicapai maka penelitian tindakan kelas ini dihentikan atau penelitian dikatakan sudah berhasil.

\section{Hasil dan Pembahasan}

Data hasil belajar pada pra siklus diperoleh nilai tertinggi adalah 90 dan nilai terendah adalah 40. Jumlah siswa yang tuntas adalah 19 orang, sedangkan jumlah siswa yang tidak tuntas adalah 22 orang. Dari data tersebut, didapatkan nilai rata-rata siswa sebesar 62,80 dan daya serap $62,80 \%$. Ketuntasan belajar sebesar 46,34\%, hal ini dikarenakan jumlah siswa yang tuntas lebih sedikit dibandingkan siswa yang tidak tuntas. Data hasil belajar pra siklus dalam PAP skala lima tergolong kategori rendah.

Kegiatan siklus I pada hasil pemberian posttest dan analisis siklus I menunjukkan nilai tertinggi 90 dan nilai terendah 40. Pada siklus I nilai rata-rata siswa adalah 68,05 dan daya serap 68,05\%. Dari jumlah siswa 41 orang, 16 siswa yang tidak tuntas karena nilai yang diperoleh belum mencapai KKM. Ketuntasan belajar diperoleh sebesar 60,98\%. Data hasil belajar dalam PAP skala lima tergolong kategori cukup. Hasil belajar siklus I mengalami peningkatan apabila dibandingkan dengan hasil pra siklus. Namun, pembelajaran yang dilakukan pada siklus I belum tuntas karena ketuntasan belajar siswa belum memenuhi syarat minimal $75 \%$. Hasil pelaksanaan tindakan yang sudah dilaksanakan di siklus I terdapat beberapa masalah yaitu sebagai berikut pertama siswa kurang berani mengemukakan pendapat. Kedua kendala pada sinyal yang membuat suara tidak dapat terdengar dengan jelas baik suara guru atau siswa. Ketiga guru kurang menghubungkan materi antara muatan pelajaran. Kemmpat siswa kadang tidak fokus dengan pembelajaran yang sedang berlangsung. Kelima beberapa siswa terkendala membuka google classroom untuk melihat materi di bahan ajar dan tugas LPKD. Sehingga, perlu adanya tindakan perbaikan dalam pembelajaran dan dilanjutkan ke pelaksanaan siklus II.

Kegiatan siklus II dengan pemberian posttest dengan soal pilihan ganda sebanyak 10 butir soal. Hasil posttest siklus II diketahui nilai tertinggi adalah 100 dan nilai terendah adalah 50. Berdasarkan hasil analisis diperoleh nilai rata-rata siswa adalah 75,85 dan daya serap $75,85 \%$. Dari jumlah siswa 41 orang, 7 siswa yang tidak tuntas karena nilai yang diperoleh belum mencapai KKM. Ketuntasan belajar yang diperoleh sebesar 82,93\%. Data hasil belajar dalam PAP skala lima tergolong kategori tinggi. Berdasarkan data siklus II, maka kegiatan pada siklus II sudah memenuhi kriteria yang ditetapkan yaitu minimal $75 \%$ bahkan lebih dari 75\%. Adapun hasil belajar yang diperoleh dari pra siklus, siklus I, dan silus II dapat dilihat pada Tabel 3.

Tabel 3. Rangkuman hasil belajar muatan IPA siswa kelas IV

\begin{tabular}{lccc}
\hline \multicolumn{1}{c}{ Data } & Pra Siklus & Siklus I & Siklus II \\
\hline Jumlah nilai & 2660 & 2790 & 3110 \\
Nilai terendah & 40 & 40 & 50 \\
Nilai tertinggi & 90 & 90 & 100 \\
Jumlah siswa tuntas & 19 & 25 & 34 \\
Jumlah siswa tidak tuntas & 22 & 16 & 7 \\
Mean & 62,80 & 68,05 & 75,85 \\
Daya serap & $62,80 \%$ & $68,05 \%$ & $75,85 \%$ \\
Ketuntasan belajar & $46,34 \%$ & $60,98 \%$ & $82,93 \%$ \\
Kategori & Rendah & Cukup & Tinggi \\
\hline
\end{tabular}


Peningkatan hasil belajar dari kegiatan pra siklus, siklus I, dan siklus II secara rinci dapat dilihat pada Gambar 2 berikut ini.

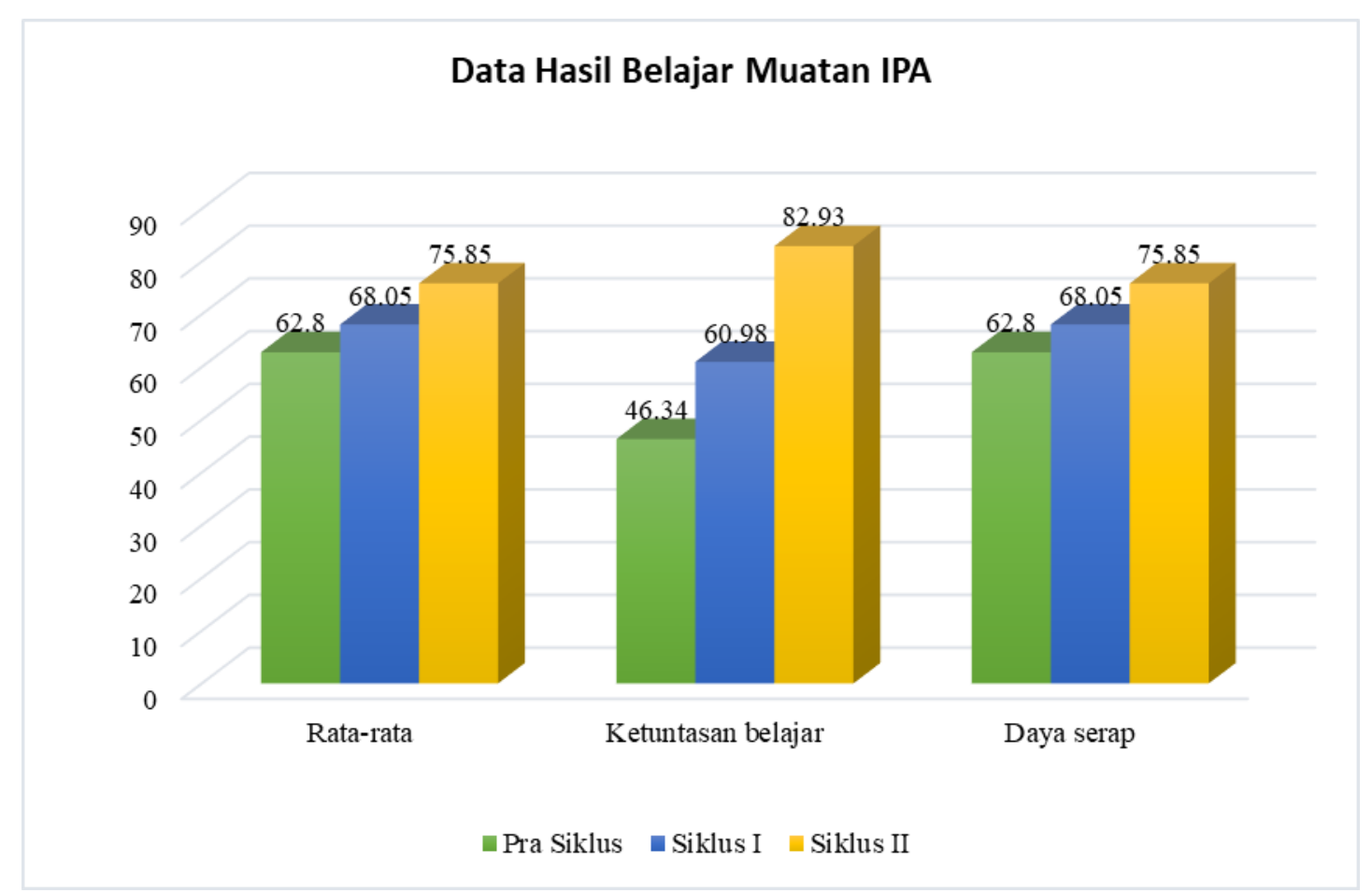

Gambar 2. Grafik Histogram Peningkatan Hasil Belajar Siswa pada Muatan IPA

Berdasarkan Gambar 2 dapat diketahui nilai rata-rata pra siklus ke siklus I mengalami peningkatan sebesar 5,25 dan nilai rata-rata siklus I ke siklu II mengalami peningkatan sebesar 7,8. Ketuntasan belajar pra siklus ke siklus I mengalami peningkatan sebesar 14,64\% dan ketuntasan belajar siklus I ke siklus II mengalami peningkatan sebesar 21,95\%. Daya serap pra siklus ke siklus I mengalami peningkatan sebesar 5,25\% dan daya serap siklus I ke siklus II mengalami peningkatan sebesar 7,8\%.

Keberhasilan peningkatan hasil belajar yang diperoleh dalam pelaksanaan penelitian ini terjadi disebabkan oleh beberapa faktor. Pertama model discovery learning lebih menekankan dan memusatkan pembelajaran pada siswa untuk mencari dan menemukan sebuah konsep dari materi yang dipelajari dengan cara mereka sendiri. Sehingga hal ini membuat siswa belajar lebih aktif dan juga siswa dapat betul-betul memahami materi dan informasi. Jadi, pembelajaran yang berlangsung mengubah pembelajaran yang pasif menjadi aktif. (Cintia, 2018; Nilayuniarti \& Putra, 2020).

Kedua, peningkatan hasil belajar siswa tidak lepas dari sintak model discovery learning yang berkaitan dengan hakikat pembelajaran IPA sebagai proses dan sikap ilmiah. Fase pertama pemberian rangsangan dengan memberikan pertanyaan-pertanyaan untuk mengarahkan persiapan siswa. Pada fase ini dapat mendorong siswa untuk berpikir kritis dan menimbulkan rasa ingin tahu siswa. Rasa ingin tahu siswa yang tinggi dapat mendorong siswa untuk lebih serius dan antusias mengikuti pembelajaran. Pembelajaran IPA menuntut siswa harus memiliki rasa ingin tahu. (Astari et al., 2018; Novelyya, 2019). Fase kedua pernyataan atau identifikasi masalah, siswa diberikan kesempatan mengidentifikasi masalah yang relevan dengan materi pelajaran. Pada fase ini mampu membuat siswa terbiasa untuk menemukan suatu masalah atau persoalan. Fase kedua model discovery learning memberikan kesempatan kepada siswa melakukan identifikasi atau mencari masalah yang sesuai dengan materi yang dipelajari. Hal ini secara tidak langsung mampu menumbuhkan sikap kritis siswa 
(Agusriyalni, 2021; Winoto \& Prasetyo, 2020). Fase ketiga pengumpulan data, siswa diberikan kesempatan melakukan berbagai aktivitas seperti melakukan percobaan atau eksperimen, membaca buku maupun bahan ajar, mengamati lingkungan dan sebagainya. Pada fase ketiga siswa mencatat semua data atau informasi yang diperoleh dari kegiatan percobaan guna menemukan konsep atau materi yang dipelajari. Hal ini secara tidak langsung telah melaksanakan yang seharusnya ada dalam pembelajaran IPA yaitu memberikan pengalaman langsung kepada siswa. Kegiatan percobaan atau eksperimen dapat mengembangkan keterampilan berpikir kritis, bekerja, dan berpikir kreatif siswa dan membuat ingatan siswa lebih lama mengenai materi (Astari et al., 2018; Sulthon, 2016). Fase keempat pengolahan data, siswa mengolah data dengan cara menganalisis data atau informasi yang didapat dengan mengerjakan tugas LKPD. Pada fase ini dapat mengembangkan sikap ilmiah siswa seperti jujur dan objektif terhadap data atau informasi yang diperoleh. Guru sebagai fasilitator memberikan membimbing dan arahan apabila siswa menemukan kesulitan dalam proses pembelajaran (Senjawati, 2020). Fase kelima pembuktian, siswa melakukan pembenaran dan pemeriksaan atas hasil temuan yang telah diperoleh melalui presentasi dan diskusi kelas dan siswa lain memberikan tanggapan atau komentar. Pada fase ini siswa dilatih untuk mengembangkan keterampilan berkomunikasi dihadapan teman dan guru secara virtual serta memunculkan sikap percaya diri. Melalui fase ini siswa memperoleh pemahaman konsep atau meteri yang dipelajari. Fase terakhir model discovery learning adalah menarik simpulan, siswa menarik suatu kesimpulan atau garis besar materi dari hasil pembuktian, masukan dari siswa lain dan penguatan dari guru.

Ketiga, penggunaan media powerpoint juga berkontribusi dalam peningkatan hasil belajar siswa karena media powerpoint yang dibuat dengan menarik menampilkan gambar maupun video dapat menarik minat belajar, merangsang semangat belajar siswa, dan pembelajaran lebih menyenangkan. Media powerpoint yang didalamnya terdapat gambar maupun video dapat membantu dalam mengatasi keterbatasan ruang dan waktu karena tidak semua hal yang berkaitan dengan materi dapat dengan mudah dibawa ke kelas. Contoh materi gaya otot pada hewan sulit untuk kita dapat membawa hewannya langsung untuk menunjukkan bahwa terdapat kegiatan manusia yang memanfaatkan otot hewan. Hadirnya media pembelajaran memiliki peran yang sangat signifikan dan membantu untuk memperjelas materi dan memberi kemudahan bagi guru. (Samura, 2015; Wahyuningtyas \& Sulasmono, 2020). Penggunaan media juga sesuai dengan tahap perkembangan siswa sekolah dasar (SD) yaitu tahap operasional konkret, yang mana kemampuan kognitif siswa masih terbatas pada hal-hal yang bersifat rumit dan abstark. Sehingga pembelajaran di sekolah dasar dilaksanakan berdasarkan sesuatu yang konkret. Pembelajaran yang memberikan persoalan yang abstrak tanpa adanya objek yang dapat diamati oleh siswa membuat siswa mengalami kesulitan dalam memecahkan persoalaan tersebut sehingga guru harus mampu menampilkan objek nyata seperti benda nyata, gambar, maupun video yang mampu ditangkap oleh siswa melalui penggunaan media pembelajaran. (Juwantara, 2019).

Keempat, pembelajaran yang berlangsung dilaksanakan dengan memberikan apresiasi dan motivasi. Pemberian apresiasi walaupun hanya berupa tepuk tangan dapat menimbulkan rasa senang, percaya diri, dan bangga pada diri siswa dan juga mampu membuat siswa terus belajar dengan baik. Pembelajaran sangat penting untuk memberikan penguatan baik penguatan verbal maupun non verbal. Penguatan verbal berupa pujian seperti "wah pintar", "bagus" dan lain-lain. Sedangkan penguatan non verbal berupa tepuk tangan, acungan jempol dan lain-lain. Penguatan tersebut agar siswa dapat tertarik untuk lebih memperhatikan pembelajaran dan termotivasi (Aini et al., 2018). Pada pembelajaran pemberian motivasi dari guru berkontribusi untuk pencapaian hasil belajar siswa. Kata-kata motivasi menjadi stimulus membuat siswa bersemangat, optimis dan tidak mudah menyerah untuk mencapai tujuan yang ingin dicapai. Motivasi dan hasil belajar memiliki hubungan yang signifikan. Apabila 
semakin baik motivasi, maka hasil belajar siswa semakin baik (Kambuno et al., 2019; M. Muhammad, 2016).

Hasil penelitian ini didukung oleh beberapa penelitian yang menyatakan bahwa terdapat peningkatan motivasi dan hasil belajar menggunakan model discovery learning pada prodi PGSD di STAHN Mpu Kuturan Singaraja (Winangun, 2020) . Penggunaan model pembelajaran discovery learning pada siswa kelas 4 sekolah dasar mampu meningkatkan keterampilan berpikir kritis dan hasil belajar matematika dari siklus I ke siklus II (Rahayu et al., 2015). Selanjutnya model pembelajaran discovery learning berbantuan virtual laboratory dapat meningkatkan motivasi dan hasil belajar siswa kelas XI IPA (Adyan et al., 2019). Penelitian memiliki kelebihan yaitu pembelajaran dilaksanakan secara daring dengan aplikasi google meet, google classroom, dan whatsapp serta penggunaan media powerpoint. Implementasi model discovery learning berbantuan powerpoint dapat memberikan implikasi yaitu pembelajaran lebih menekankan pada aktivitas siswa, adanya media pembelajaran siswa lebih tertarik, melalui penemuan materi diingat lebih lama, pembelajaran yang dilaksanakan meningkatkan kemampuan berpikir kritis. Implikasi penelitian ini masih memiliki beberapa kekuarangan karena keterbatasan pada penelitian. Berdasarkan hal tersebut adapun rekomendasi berikutnya adalah pembelajaran dapat dilakukan pada materi dan mata pelajaran yang berbeda dan menggunakan platform yang lebih beragam.

\section{Simpulan}

Implementasi model discovery learning berbantuan powerpoint dapat meningkatkan hasil belajar IPA siswa kelas IV. Sehingga, model ini dapat direkomendasikan untuk diterapkan pada semua jenjang dan materi yang berbeda serta media pembelajaran inovatif.

\section{Daftar Rujukan}

Adyan, F. B., Purwanto, A., \& Nirwana, N. (2019). Upaya Meningkatkan Motivasi dan Hasil Belajar Siswa dengan Model Discovery Learning Berbantuan Virtual Laboratory. Jurnal Kumparan Fisika, 2(3), 153-160. https://doi.org/10.33369/jkf.2.3.153-160.

Agung, A. A. G. (2010). Pengantar Evaluasi Pendidikan. Fakultas Ilmu Pendidikan.

Agusriyalni. (2021). Penerapan Model Discoery Learning pada Materi Sistem koordinasi untuk Meningkatkan Hasil Belajar Peserta Didik. Diklabio: Jurnal Pendidikan Dan Pembelajaran Biologi, 5(1), 31-39. https://doi.org/https://doi.org/10.33369/diklabio.5.1.31-39.

Aini, H., Suandi, N., \& Nurjaya, G. (2018). Pemberian Penguatan (Reinforcement) Verbal dan Nonverbal Guru dalam Pembelajaran Bahasa Indonesia di Kelas VIII MTSN Seririt. Jurnal Pendidikan Bahasa Dan Sastra Indonesia Undiksha, 8(1), 23-32. https://doi.org/10.23887/jjpbs.v8i1.20246.

Asriani, Pahriadi, S. S. (2021). Pengaruh Model Pembelajaran Kreatif Produktif Berbantuan Media Visual terhadap Hasil Belajar Siswa pada Mata Pelajaran IPA di Kelas V. Educate Jurnal Teknologi Pendidikan, 6(1), 1-8. https://doi.org/10.32832/educate.v6i1.3939.

Astari, F. A., Suroso, S., \& Yustinus, Y. (2018). Efektifitas Penggunaan Model Discovery Learning dan Model Problem Based Learning terhadap Hasil Belajar IPA Siswa Kelas 3 SD. Jurnal Basicedu, 2(1), 1-10. https://doi.org/10.31004/basicedu.v2i1.20.

Azizah, M., Rofian, \& Sholikhah, I. R. (2021). Penggunaan Media Montase untuk Meningkatkan Kemampuan Berpikir Kritis Siswa pada Mata Pelajaran IPA. Jurnal Pendidikan Dan Pengajaran Guru Sekolah Dasar (JPPGusseda), 04(01), 65-69. https://doi.org/10.33751/jppguseda.v4i1.3279.

Cintia. (2018). Penerapan Model Pembelajaran Discovery Learning untuk Meningkatkan 
Kemampuan Berpikir Kritis dan Hasil Belajar Kimia. Perspektif Ilmu Pendidikan, 32(1), 23. https://doi.org/10.23887/jpk.v1i1.12808.

Elisa, N., Nuriman, \& Mutrofin. (2013). Penerapan Model Pembelajaran Quantum Teaching untuk Meningkatkan Motivasi dan Hasil Belajar IPA pada Siswa Kelas V di SDN Kemuningsari Kidul 01 Jenggawah Tahun Pelajaran 2013-2014. Artikel Ilmiah Mahasiswa, 1(1), 1-7. http://repository.unej.ac.id/handle/123456789/59799.

Jarre, A. R., \& Bachtiar, S. (2017). Aktivitas dan Hasil Belajar Kognitif Siswa Meningkat melalui Penerapan Model Jigsaw. Jurnal Biologi \& Pembelajarannya, 4(1), 26-33. https://doi.org/https://doi.org/10.29407/jbp.v4i1.672.

Juwantara, R. A. (2019). Analisis Teori Perkembangan Kognitif Piaget pada Tahap Anak Usia Operasional Konkret 7-12 Tahun dalam Pembelajaran Matematika. Al-Adzka: Jurnal Ilmiah Pendidikan Guru Madrasah Ibtidaiyah, 9(1), 27. https://doi.org/10.18592/aladzkapgmi.v9i1.3011.

Kambuno, A. Y., Aminuyati, \& Okianna. (2019). Pengaruh Pemberian Motivasi oleh Guru Mata pelajaran PPKn terhadap Hasil Belajar Siswa Kelas X. Jurnal Pendidikan Dan Pembelajaran Khatulistiwa, $\quad 8(9), \quad 1-9$. https://jurnal.untan.ac.id/index.php/jpdpb/article/view/35772.

Kusumah, R. G. T., Walid, A., Pitaloka, S., Dewi, P. S., \& Agustriana, N. (2020). Penerapan Metode Inquiry sebagai Usaha untuk Meningkatkan Hasil Belajar IPA pada Materi Penggolongan Hewan di Kelas IV SD Seluma. Jurnal Pendidikan Matematika Dan IPA, 11(1), 142-153. https://doi.org/10.26418/jpmipa.v11i1.34708.

Muhammad, H. (2015). Pengembangan Kinerja Guru Melalui Penelitian Tindakan Kelas pada SMA Negeri di Kota Palopo. Lentera Pendidikan: Jurnal Ilmu Tarbiyah Dan Keguruan, 18(2), 152-170. https://doi.org/10.24252/lp.2015v18n2a2.

Muhammad, M. (2016). Pengaruh Motivasi Dalam Pembelajaran. Lantanida Journal, 4(2), 87. https://doi.org/10.22373/1j.v4i2.1881.

Mulyasa. (2013). Praktik Penelitian Tindakan Kelas. PT Remaja Rosdakarya.

Nilayuniarti, N. P., \& Putra, D. K. N. S. (2020). Meningkatkan Kompetensi Pengetahuan IPS melalui Model Pembelajaran Discovery Learning Berbasis Tri Hita Karana. Mimbar PGSD, 8(3), 445-456. https://ejournal.undiksha.ac.id/index.php/JJPGSD.

Novelyya, S. (2019). Pengaruh Karakter Rasa Ingin Tahu Siswa terhadap Hasil Belajar Mata Pelajaran IPA Fisika di SMP Negeri 08 Muaro Jambi. Briliant: Jurnal Riset Dan Konseptual, 4(2), 174. https://doi.org/10.28926/briliant.v4i2.291.

Nurhidayati, Asrori, I., Ahsanuddin, M., \& Dariyadi, M. W. (2019). Pembuatan Media Pembelajaran Berbasis Powerpoint dan Pemanfaatan Aplikasi Android untuk Guru Bahasa Arab. Jurnal KARINOV, 2(3), 181. https://doi.org/10.17977/um045v2i3p181184.

Nurqomariah, Gunawan, S. (2015). Pengaruh Model Problem Based Learning dengan Metode Eksperimen terhadap Hasil Belajar IPA Fisika Siswa Kelas VII. Jurnal Pendidikan Fisika Dan Teknologi, I(3), 173-178.

Purwanti, L., Widyaningrum, R., \& Melinda, S. A. (2020). Analisis Penggunaan Media Power Point dalam Pembelajaran Jarak Jauh pada Materi Animalia Kelas VIII. Journal Of Biology Education, 3(2), 157. https://doi.org/10.21043/jobe.v3i2.8446.

Rahayu, R. D. Y., Mawardani, \& Astuti, S. (2015). Peningkatan Keterampilan Berpikir Kritis melalui Model Pembelajaran Discovery Learning. Jurnal Pendidikan Dasar Indonesia, 4(1), 8-13. https://doi.org/10.29303/jppipa.v1i2.20.

Razi, Z. M. (2019). Model Discovery Learning Berbantuan Software Maple terhadap Kemampuan Pemahaman Matematis. AKSIOMA:Jurnal Pendidikan Matematika FKIP Univ. Muhammadiyah Metro, 8(3), 520-527. http://journal.unigha.ac.id/index.php/SemNas/article/view/343. 
Rosarina, G., Sudin, A., \& Sujana, A. (2016). Penerapan Model Discovery Learning untuk Meningkatkan Hasil Belajar Siswa pada Materi Perubahan Wujud Benda. Jurnal Pena Ilmiah, 1(1), 371-380. https://doi.org/10.17509/jpi.v1i1.3043.

Samura, A. O. (2015). Penggunaan media dalam Pembelajaran Matematika dan Manfaatnya. Delta-Pi: Jurnal Matematika Dan Pendidikan Matematika, 4(1), 69-79. http://dx.doi.org/10.33387/dpi.v4i1.145.

Senjawati. (2020). Peran Guru Kelas dalam Meningkatkan Pemahaman Siswa Pada Pembelajaran IPA melalui Pembelajaran Berbasis Etnosains. Integrated Science Education Journal, 1(2), 46-50. https://doi.org/10.37251/isej.v1i2.78.

Siboro, N. N. (2020). Peningkatan Hasil belajar PKN dengan Menggunakan Media Pembelajaran Powerpoint pada Siswa Kelas IX-1 SMP Negeri 1 Patambuk. Jurnal Sekolah, 4(2), 134-140. https://doi.org/doi.org/10.24114/js.v4i2.17969.

Sri Udayanti, I. A. G., \& Nanci Riastini, P. (2017). Penerapan Metode Take and Give untuk Meningkatkan Hasil Belajar IPA Siswa Kelas IVA. Jurnal Ilmiah Sekolah Dasar, 1(1), 51. https://doi.org/10.23887/jisd.v1i1.10118.

Sulthon. (2016). Pembelajaran IPA yang Efektif dan Menyenangkan bagi Siswa Madrasah Ibtidaiyah (MI). ELEMENTARY: Islamic Teacher Journal, 4(1). https://doi.org/10.21043/elementary.v4i1.1969.

Sutama, I. N. (2020). Penerapan Model Pembelajaran Kooperatif Berbantuan Media Power Point untuk Meningkatkan Hasil Belajar Tematik Tema Indahnya Kebersamaan Siswa. Jurnal Iovasi, 6(4), 58-63. http://jurnalinovasi.my.id/index.php/IJG/article/view/124.

Tembang, Y., Harmawati, D., \& Rahajaan, J. P. (2019). Peningkatan Hasil Belajar IPA Siswa melalui Penerapan Model Pembelajaran Kooperatif Tipe Group Investigation di Sekolah Dasar. Jurnal Ilmiah Sekolah Dasar, 3(2), 230. https://doi.org/10.23887/jisd.v3i2.17643.

Wahyuningtyas, R., \& Sulasmono, B. S. (2020). Pentingnya Media dalam Pembelajaran Guna Meningkatkan Hasil Belajar di Sekolah Dasar. Edukatif: Jurnal Ilmu Pendidikan, 2(1), 23-27. https://doi.org/10.31004/edukatif.v2i1.77.

Whesli, H., Tyas, A., Hardini, A., Kristen, U., \& Wacana, S. (2021). Peningkatan Hasil Belajar IPA dengan Discovery Learning Berbantuan Media Audio Visual di Sekolah Dasar. Edukatif: Jurnal Ilmu Pendidikan, 3(3), 698-704. https://doi.org/https://doi.org/10.31004/edukatif.v3i3.345.

Winangun, I. M. A. (2020). Penerapan Model Discovery Learning Berbasis Digital untuk Meningkatkan Motivasi dan Hasil Belajar Mahasiswa pada Mata Kuliah Media Pembelajaran SD. E- Jurnal Mitra Pendidikan, 4(5), 256-268. https://doi.org/10.52160/e-jmp.v4i5.722.

Winoto, Y. C., \& Prasetyo, T. (2020). Efektivitas Model Problem Based Learning dan Discovery Learning terhadap Kemampuan Berpikir Kritis Siswa Sekolah Dasar. Jurnal Basicedu, 4(2), 228-238. https://doi.org/10.31004/basicedu.v4i2.348.

Zairmi, U., Fitria, Y., \& Amini, R. (2019). Penggunaan Model Pembelajaran Two Stay Two Stray dalam Pembelajaran IPA dI Sekolah Dasar. Jurnal Basicedu, 3(4), 1031-1037. https://doi.org/10.31004/basicedu.v3i4.221. 